\title{
Global Epistemic Injustice: An Ethical Confrontation With Jihadism
}

\author{
Hager Ben Driss \\ Université de Tunis \\ bendrisshager@gmail.com
}

\begin{abstract}
The aim of this article is to press the borders of philosophy to the terrain of literary studies and praxis of teaching. Starting from Kamila Shamsie's novel Home Fire, I try to enlarge the frame of Miranda Fricker's discussion of epistemic injustice. Fricker's concern with everyday epistemic micro-aggressions can serve as a model of investigating global epistemic injustices. Shamsie's narrative about terrorism offers clear instances of testimonial injustice that fuse in other forms of injustices and form a continuum of epistemic injustice. Bringing the issue of terrorism and jihadism to the classroom and addressing it through philosophical epistemic lenses provides a precious occasion for an ethical confrontation with it. It is also a way to trespass the boundaries between the classroom and the outside world. The discussion with students raises the question of empathy, as constitutive of ethics, and looks into its limits.
\end{abstract}

"The end of great books is ethical - to teach us what it means to be genuinely human." (Russell Kirk, 1981)

"Some people are selective about their empathy; believing that they should only use it for a certain group of people. If you're a novelist, it's just part of your professional life to empathize very widely in order to find human stories everywhere." (Kamila Shamsie, 2018)

\section{Introduction}

This article has its genesis in the classroom. Teaching Pakistani Kamila Shamsie's Home Fire (2017), a novel about jihadism, among several other issues, I had to grapple, along with my students, with issues of ethics, in/justice, empathy, and global politics. Bringing the topic of terrorism to the classroom is a challenging venture. Despite its riveting and pervasive nature, terrorism remains a sensitive, sometimes a taboo, subject. The challenge, in my experience of teaching this novel, operates on two fronts: pedagogical and situational. The pedagogical level revolves around the tense relationship between the aesthetic and the socio-political sides in the reading/teaching operation of a literary text. Harold Bloom, for instance advocates an exclusive aesthetic approach. His claim that reading "does not teach anyone to become a better citizen" (Bloom, 1994, p. 519), or his contention that "the aesthetic is an individual and not a social concern" (Bloom, 2015) isolates both reader and text from the world. On the other far side of this dialogue, Ngugi WaThiong'o contests such a reductive conception of teaching, and ascribes it to a long tradition bequeathed by Western education, which is conducive to a compartmentalized vision. He argues that "nothing exemplifies this attitude better than our approach as teachers of literature to questions of art and aesthetics. What has aesthetics to do with environment?... What does it have to do with questions of poverty in Africa, or wealth in 
the West? Literature, in particular, is taught as if it had nothing to do with these 'other' realms of our being" (WaThiong'o, 2000, p. 120). WaThiong'o calls for a teaching praxis based on aesthetic and ethical bridges and connections, which is a position I embrace and try to implement in my classroom. Indeed, my teaching of Shamsie's Home Fire is driven by a major objective, one that enhances critical thinking with an alert eye to the intertwined relationship between the ethical and the socio-political coordinates in a literary text.

The second challenge, which I call situational, deals with the geographical setting of my course. Since 2011, Tunisia has registered several terrorist attacks, while a great number of young Tunisians have been recruited by ISIS. In 2015, two assaults, one on the Bardo Museum in Tunis, another on a Hotel in Sousse, show that the country was transformed into a land of both recruitment and jihad. These terrorist groups, however, represent a minority and lack popular support. The concerted resentment against terrorism is tightly linked to a general apprehension that these attacks target the burgeoning democratic transition in Tunisia. Second year students attending this class of Anglophone literature, and whose average age is twenty, are particularly attentive to the political situation of the country. They make up a postrevolution generation which has enjoyed full liberty of expression and is, therefore, aware of potential threats to freedom. Teaching Home Fire in Tunisia is a pedagogical minefield compounded by the political and ethical nature of the issue the book addresses. Shamsie's narrative subverts the typical discussion of terrorism, often based on a straightforward reviling of the terrorist figure. It rather provokes a deliberately nuanced debate enhancing the reader to question the empathy shortfall informing narratives of terrorism. How to speak about empathy in a context of jihadism is one of the problematic questions that raises antagonistic feelings among students. The novel, which is a modern rewriting of Sophocles'Antigone, functions as an "open work", in Umberto Eco's (1989) phrasing, wherein "the individual addressee is bound to supply his [her] own existential credentials, the sense conditioning which is peculiarly his [her] own, a defined culture, a set of tastes, personal inclinations, and prejudices" (p. 3). This category of texts baffles the objective reader, and incites a dynamic and participatory act of reading.

A rewarding reading of Shamsie's novel can be energized by opening up venues of dialogue between philosophy and literature. Philosophers who were also associated with literature, such as Nietzsche, Heidegger, Gadamer, Goodman, Derrida, and several others, attest to the shared concerns of the two professions. Miranda Fricker's philosophical reading of a literary text to exemplify her concept of testimonial and hermeneutic injustice provides another evidence of the epistemic affinity between literature and philosophy. Fricker's Epistemic Injustice (2007) bears significantly on my reading of Home Fire. My analysis attempts to complicate issues of epistemic injustice related to the controversial debate around terrorists and jihadists. The aim of this article is to press the boundaries of epistemic injustice as a philosophical concept to the realm of literary studies as well as praxis of teaching. Among the thorny questions that provoke a heated debate in the classroom are: Can we trust a repentant terrorist? Should jihadists be accepted back home and reintegrated in society? Do they have the right to speak? Translated into philosophical parlance, these queries would yield the following questions: Can jihadists be accepted as epistemic agents? If we refuse to listen to them, do they constitute a case of testimonial injustice? Being marginalized from epistemic production, do they offer a case of hermeneutic injustice? The novel confronts the reader with a rather difficult ethical responsibility. If the ultimate purpose of literature is to cultivate empathy, is there a limit to such empathy? 


\section{One More Antigone: A Variation on a Myth}

Sophocles' two-and-a-half-millennia-old play has secured its longevity through several adaptations and rewritings. The vexed relationship between ethics and politics, being the fulcrum of the play, is recuperated in the myriad of adaptations in different languages and cultures. Jean Anouilh's Antigone (1944), for instance, written under the Nazi occupation of France, shares the same spirit of resistance energizing Athol Fugard's The Island (1973), written and performed under the oppressive apartheid regime. What makes Antigone an enduring iconic work is its ever timely subject matter: the unremitting collision between state power and opposition to authority. This is because, according to Rosanna Lauriola, "there might always be a Creon who, differently disguised, represents some kind of abusive power, some sort of authority deaf to conscience. In consequence, there might always be the need for an Antigone as a reminder of rights and responsibilities that should not be abdicated in the face of that power and authority, but should be bravely defended" (Lauriola, 2014, p. 46). This sense of fortitude face to justice deficit is at the heart of Shamsie's revisiting of the Greek play.

Sophocles' Antigone is about the aftermath of a civil war opposing two brothers. Etiocles breaches an agreement with his brother Polynices that each would take the throne from one year to the next, and refuses to step down. Polynices marches on Thebes, his army is defeated, and the two brothers kill each other in a duel. The new King Creon enforces a decree that bans the burial of Polynices whom he considers a traitor. Antigone, Polynices' sister, oversteps the royal edict and buries her brother. In retaliation, Creon condemns her to death. A similar confrontation between polis (state) and oikos (family) steers a path at the heart of Shamsie's Home Fire, a narrative that sticks to Sophocles' basic storyline. The novel, which is a modern take on Antigone, narrates the stories of three British siblings with Pakistani origins. The nineteen-year old Parvaiz (standing for Polynices in the Greek play), who has a remarkable gift of dealing with sound effects, is manipulated by an ISIS recruiter and duped into joining jihadists in Syria. There, he is given the mission of adding sounds to the terrorists' videos registering executions of infidels. Disillusioned, Parvaiz manages to escape to Turkey where he expects to meet his twin sister Aneeka (the counterpart of Antigone) and safely go back to London. But he is assassinated by an ISIS agent and his corpse is deported to Pakistan, as Karamat, the Home Secretary (standing for Creon), not only revokes his citizenship but also refuses his burial on the British soil. Aneeka, who joins her brother's corpse in Pakistan, insists to take him back to London and sits besides the rotting body as a protest against the unjust law.

While Shamsie refers to three works in her "Acknowledgments", namely Anne Carson's Antigone (2015), Seamus Heaney's The Burial at Thebes (2005) and Ali Smith's The Story of Antigone (2013), that were constant companions as she wrote her novel, Heaney's adaptation seems to bear significantly on her text. The epigraph of the novel, "The ones we love ... are enemies of the state", quoted from Heaney's translation and placed at the threshold of the book, opens up specific corridors of interpretation. Indeed, Heaney, who considers Antigone a "political allegory", makes of his adaptation a vocal critique of the American war on terror. Explaining the need for a new version, he states:

Early in 2003 we were watching a leader, a Creon figure if ever there was one: a law and order bossman trying to boss the nations of the world into uncritical agreement with his edicts in much the same way as Creon tries to 
boss the Chorus of compliant Thebans into conformity with his. With the White House and the Pentagon in cahoots, determined to bring the rest of us into line over Iraq, the passion and protest of an Antigone were all of a sudden as vital as oxygen masks. (Heaney, 2005)

Shamsie's narrative equally engages in the aftermath of 9/11 attacks and the global war on terrorism, which intensified after the 2011 Arab Revolutions. Taliban, now defeated after the liquidation of Osama Bin Laden, cedes space for a more ferocious terrorist group, ISIS, which recruits fighters from all over the world, including western countries.

The war on terror and terrorists backdrops the story behind Shamsie's story. Asked by a theatre director to re-write the ancient Greek play in a contemporary context, Shamsie opted to bring stage to page and write a novel. After reading the play, she felt the urge to connect it to a story that was very much in the news, "young Britons, often teenagers, going to join a barbaric regime - and understand it at the human level, via the prism of a 2000-year-old story of family and grief and love" (Shamsie, cited in Koski, 2018). If they are dual nationals, these young jihadists are legally deprived of citizenship, while being British-born does not exempt them from being banished from the country. The home secretary has this deprivation power; he/she can exile at his/her sole discretion anybody who endangers the national security. Shamsie's narrative problematizes this "two-tiered system of justice", which institutionalizes cultural prejudice by "distinguishing between those who are 'British British' and those who are British until the home secretary decides otherwise" (Shamsie, 2018). Conjugating ethics and politics, the novel raises an urgent need to rethink questions of in/justice. These jihadists whose citizenship is revoked without proper trials, in other words without being heard, provoke a pertinent debate around forms of epistemic violence or epistemic injustice.

\section{Epistemic Violence and Epistemic Injustice: Can the Jihadist Speak?}

Miranda Fricker's Epistemic Injustice is hailed as presenting a breakthrough in bringing ethics and epistemology together. In Fricker's (2007) phrasing, the book "renegotiates a stretch of the border" (p. 2) between epistemology and ethics. The major innovation sustaining the book's arguments resides in an exclusive focus on injustice, rather than justice, as "philosophy seems to shun injustice", a statement by Judith Shklar that Fricker uses as the epigraph of her book. One form of epistemic injustice investigated in the book is "testimonial injustice", which "occurs when prejudice causes a hearer to give a deflated level of credibility to a speaker's word" (Fricker, 2007, p. 1). This credibility deficit is based on an identity prejudice (gender, class, race) and consequently divests the speaker from his/her capacity as a knower or an agent of knowledge production. Epistemic injustice, therefore, "wrongs someone in their capacity as a subject of knowledge" (p. 4). If someone is rejected as a knower, they are systematically denied the right to be heard. The question then is not an inability to speak, but rather a deficit in listening. This is precisely the central task of Gayatri Spivak's theorization of epistemic violence, something Fricker fails to acknowledge in her book.

While Fricker investigates this damage in everyday testimonial exchanges, Spivak (1988), in her article "Can the Subaltern Speak?", explores the same wrong by focusing on cultural exchanges in a colonial context, wherein marginalized groups are silenced and denied epistemic agency. Such a linguistic reciprocation, based on a transaction between a speaker and a hearer, as defined by Fricker, is also at the heart of Spivak's theorization of epistemic violence. What Fricker calls testimonial injustice is a component of epistemic violence, 
wherein "entire populations of people can be denied this kind of linguistic reciprocation as a matter of course" (Dotson, 2011, p. 238). In an interview by Sneja Genew, Spivak expands on the question she raised two years before: "Can the Subaltern Speak?", which triggered a heated debate, as she states, "for me, the question 'who should speak?' is less crucial than 'Who should listen?"' (Spivak, 1990, p. 59). In 2017, Spivak revisited this question in a paper she presented in the International Book Fair of Tunis. She considers that the Tunisian revolution offers a case in which "the subaltern's speech act" is completed because it is heard. Such a speech act is usually "not completed and therefore, technically, even if subaltern groups attempt to speak, they are not heard, and therefore they are judged incapable of prendre la parole, they cannot speak when speaking" (Spivak, 2017). Epistemic violence, then, raises the same philosophical concerns expressed in epistemic injustice: Who speaks and who listens? If you speak, will there be someone who listens to you? And if there is someone who listens, how will they listen to you?

In an article astutely titled "Sound and Fury: Kamila Shamsie's Home Fire", Claire Chambers (2018) claims Spivak as being her "main influence in adopting [an] auditory line of inquiry" (p. 203). Tracing the sonic agenda of different characters, Chambers tries to answer a pertinent question: "Can the oppressor listen?" The article, however, does not fully explain the process of silencing in the novel, and hints furtively at the ethical nature of listening. My article ventures to take up where Chambers leaves off. While integrating epistemic violence and epistemic injustice, I propose to reroute Fricker's model of testimonial injustice and its attending concepts to the field of postcolonial and cultural studies. As Spivak's work intersects productively with the concerns at the heart of epistemic injustice, my addenda "Can the jihadist speak?" may find an adequate answer in using Fricker's terminology. The jihadist in Shamsie's narrative is given voice but denied credibility. Parvaiz is given a whole section in the novel wherein a limited omniscient narrator exposes his thoughts and feelings. The young to-be-jihadist is a family-oriented brother, a promising artist, and a committed citizen. This textual depiction aimed at disrupting the clichéd image of the violent terrorist is counterbalanced by other competing texts/voices in the narrative. Shamsie, for instance, inserts the following tweets which indict Parvaiz without ever listening to him: “\#WOLFPACK”, “\#PERVYPASHA”, “\#DONTSULLYOURSOIL”, and "\#GOBACKWHEREYOUCAMEFROM". These textual scraps vocalizing a common antagonism to jihadists serve as a reminder that what is more important than a jihadist's voice is the credibility deficit, or "prejudice in the economy of credibility" (Fricker, 2007, p. 1), that marks anything he may say. Such a deficit inflates with a hostile media coverage and tabloid versions of Parvaiz's story. One article inserted into the narrative openly celebrates the liquidation of Parvaiz: "her twin brother was fortunately killed while trying to enter the British Consulate in Istanbul" (Shamsie, 2017a, p. 204). The extreme form of epistemic injustice in the novel is the one presented by the home secretary Karamat, whose attitude stands for an official, institutionalized, injustice that targets epistemic communities. Indeed, Karamat announces: "I revoked the citizenship of all dual nationals who have left Britain to join our enemies" (p. 188). Consequently, Parvaiz does not represent an individual case; he rather joins a whole community of immigrants. If the home secretary has the prerogative to revoke someone's citizenship without trial, then the question: "Can the jihadist speak?" is also a question about epistemic injustice. The jihadist cannot speak because nobody will listen. Shamsie's novel offers an interesting terrain wherein questions of epistemic injustice amalgamate the individual and the collective, and operate on a global level.

\section{Epistemic Injustice: Continua and Connections}

Journal of Contemporary Issues in Education, 2020, 15(2), pp. 23-35. 
I explore in this section the way epistemic injustice operates as a continuum or a chain of situations or events that pass into one another and cannot be readily distinguished. Starting from testimonial injustice, I will show that credibility deficit is enmeshed with mobility injustice and surveillance, which both stand as cases of epistemic coercion. Fricker calls this chain of connections a "systematic" injustice, wherein a person becomes a "subject to a tracker prejudice" and "renders one susceptible not only to testimonial injustice but to a gamut of different injustices, so when such a prejudice generates testimonial injustice, that injustice is systematically connected with other kinds of actual or potential injustice" (Fricker, 2007, p. 27). In other words, a prejudice which seems to operate only within a linguistic exchange, often as a micro-aggression, is in reality dissolved into an infinity of traces "that 'track' the subject through different dimensions of social activity - economic, educational, professional, sexual, legal, political, religious, and so on" (p. 27). This continuum of connected prejudices forms a habitus of epistemic injustice which functions on local as well as global levels. The airport episode, which shows a clear case of testimonial injustice, generates two other intertwined damages: a coercive immobility and a violation of privacy.

\section{Isma: A case of testimonial injustice}

Shamsie opens her narrative with an interrogation scene at Heathrow airport. British born Isma Pasha, with Pakistani origins, is detained at the airport and interrogated for several hours. Aveiled dual-national Muslim citizen, with a father who fought in Afghanistan and a brother who has joined ISIS, Isma offers a complicated case of what Fricker calls "a negative identity-prejudicial stereotype", which she defines as "a widely held disparaging association between a social group and one or more attributes, where this association embodies a generalization that displays some (typically, epistemically culpable) resistance to counterevidence owing to an ethically bad affective investment" (Fricker, 2007, p. 35). Isma's name, dark complexion, and veil locate her immediately into a specific category often interrogated at length at airports. Aware of this prejudice and what it entails in spaces of transit, Isma, the narrator tells us, "made sure not to pack anything that would invite comment or questions - no Quran, no family pictures, no books on her areas of academic interest" (Shamsie, 2017a, p. 3). Hiding elements which form her identity (religious, familial, and educational) is one part of what Kristie Dotson calls "testimonial smothering", which "occurs because the speaker perceives one's immediate audience as unwilling or unable to gain appropriate uptake of proffered testimony" (Dotson, 2011, p. 244). Indeed, Isma has to rehearse her testimony at home with her sister, anticipate questions, and select appropriate answers. She plays the role of a speaker "of dubious political opinions." Her task is to "avoid voicing strenuously opposing views" without lying, either (Shamsie, 2017a, p. 5).

Because she knows that she will confront an unsafe and risky testimonial exchange, Isma is obliged to conceal her knowledge and, therefore, she is wronged as a knower. In an interrogation, which continues "for nearly two hours" with one officer, Isma is asked to provide her thoughts "on Shias, homosexuals, the Queen, democracy ..., the invasion of Iraq, Israel, suicide bombers, dating websites" (Shamsie 2017a, p. 5). Face to this gamut of queries, she uses rather evasive answers such as "when people talk about the enmity between Shias and Sunni it usually centres around some political imbalance of power, such as in Iraq or Syria- as a Brit, I don't distinguish between one Muslim and another"; or "occupying other people's territory generally causes more problems than it solves'- this served for both Iraq and Israel" (Shamsie, 2017a, p.5). The testimonial injustice here is clear: the hearer's questions are orchestrated in a manner to gauge the speaker's ideology and use her answers as 
evidence supporting his prejudice. Limiting a speaker's speech or obliging her to take a discursive detour is called by José Medina (2017) an "epistemic death" which "calls for epistemic disobedience and epistemic insurrection" (p. 46). Isma is deprived of her agency as a knower and obliged to adopt an epistemic subterfuge. The insidious process of epistemic objectification deprives Isma of the status of "informant", a subject endowed with epistemic agency, and relegated to the status of "source of information", an object from which the interrogator culls information (Fricker, 2007, p. 133).

Isma's epistemic stratagem, however, proves inefficient face to a question she has failed to anticipate:

'Do you consider yourself British?' the man said.

'I am British.'

'But do you consider yourself British?' (Shamsie, 2017a, p. 5)

As the officer's question stems from an identity prejudice, Isma is wronged in her capacity as a knower. The officer's "but" not only discredits her knowledge, but also posits Isma in a racial category of "sub-knowers" (Pohlhaus, 2017, p. 17). This prejudice is also clear in the first interrogation carried by a woman officer, and goes beyond testimonial injustice, as Isma is even denied testimony or epistemic agency. The officer does not ask a question; she provides a matter-of-fact statement. Holding Isma's design jacket, she says: "This isn't yours", mentally translated by Isma as "it's too nice for someone like you" (Shamsie, 2017a, p. 3). Isma's explanation of the origin of the jacket, being a gift by a customer of the drycleaning shop where she used to work, is received with a straightforward suspicion: "does the manager know you took it?" (p. 3). The officer here shows a deliberate epistemic violence not only through a credibility deficit, but also through epistemic denial.

\section{Mobility injustice}

Shamsie's fictional rendering of testimonial injustice aptly recreates such an injustice in real life. As an aftermath of 9/11, airports are transformed into "a surveillance machine" (Salter, 2008, p. 35). Epistemic injustice operates now on a global level. It targets specific ethnic groups and veers towards race prejudice. This is the case of British-Asian Riz Ahmed, a rap singer and actor, who offered a poignant testimony dealing with the traumatic interrogations hewent through in European and American airports. Back home to London from Berlin Film Festival, where the film he starred won a prestigious award, he was violently arrested and interrogated at the airport. The film, titled The Road to Guantanamo, "told the story of a group of friends from Birmingham who were illegally imprisoned and tortured in the US detainment camp." Detained, "insulted", "threatened" and physically attacked, Riz Ahmed had to answer the following questions: "What kinda film you making? Did you become an actor to further the Muslim struggle?" (Ahmed, 2016). Similar to Isma in Shamsie's narrative, who is subjected to an emotional violence, Riz Ahmed's "epistemic wrong bears a social meaning to the effect that the subject is less than fully human. When someone suffers a testimonial injustice, they are degraded qua knowers, and they are degraded qua humans" (Fricker, 2007, p. 44). Ahmed and Isma share the same feeling of humiliation at being detained, immobilized, and interrogated.

The epistemic injustice Isma faces at the airport fuses with another type of injustice, namely mobility injustice. She is not only wronged as an epistemic agent, she is also denied free movement. Isma is coerced into immobility for several hours; she even misses her flight. The 
narrative confronts the questions raised by Anne-Marie Fortier (2014): "who moves freely and who doesn't? How does one's place of residence on the planet frame one's capacity to leave or travel, if one desires so?" (p. 66). In the case of Isma, we should add, how can one's race and religion impede one's fluid circulation? Mobility injustice, in its local as well as global forms, is enmeshed with "embodied differences in class, gender, ethnicity, nationality, sexual identity and physical ability" (Sheller, 2018, p. 18). These are the same elements that interact with epistemic regimes and unequal testimonial conditions. The unsafe testimonial situation, which the airport episode offers, cannot easily be distinguished from the precarious access to mobility.

\section{Surveillance as epistemic injustice}

The opening scene in Shamsie's narrative shows a continuum in epistemic injustice. Testimonial injustice not only dissolves into unequal mobility, it also exposes traces of surveillance. Isma's interrogation is punctuated by "long intervals of silence between each answer and the next question as the man clicked on her laptop, examining her browser history" (Shamsie, 2017, pp. 5-6). While the long intervals of silence are meant to destabilize her as a knower, investigating her browser history is a coercive act of gathering knowledge. The narrative raises concerns about digital surveillance. The acronym "GWM", or "Googling While Muslim" is a joke Shamsie uses in her novel to refer to the dangers that a Muslim can run if he/she makes a research on the internet on terrorism or jihadism. Shamsie herself experienced this moment while working on Home Fire and researching the online recruiting of radicals:

I was surprised by the extent to which I was conscious of this. I found myself building up a justification as to what I would say if someone came to ask me why I was looking at these websites... There was this sense of living in a surveillance state. My agent knew what I was working on, but I found myself doing strange things like thinking I had looked at too many of those websites in a row and so I should look at some pop culture. Certain images I absolutely didn't want to see, so I relied on others who have seen them. I was interested in interviews with people who had been into Raqqa and come out. (Shamsie, 2017b)

Shamsie here describes her feelings of insecurity before she was given British citizenship. Actually, "she would not have dared to write the book before becoming a British citizen, in 2013, for fear that someone at the UK Border Agency or Home Office ... would have taken against the novel and used it as an excuse to turn down her citizenship application" (Nicol, 2017). Surveillance curtails knowledge acquisition and therefore stymies epistemic transactions.

Such a surveillance state, collecting and storing information about people, functions as a huge Panopticon. Foucault starts from Bentham's Panopticon, a prison design, to formulate a theory about vision and supervision. The Panopticon is a circular building divided into cells and supervised by a central tower. It is "a machine for dissociating the see/being seen dyad", explains Foucault, wherein an incarcerated person "is seen, but he does not see; he is the object of information, never a subject in communication" (Foucault, 1995, p. 200). Foucault's use of Bentham's prison model to theorize an apparatus of surveillance shows that the ultimate goal of this system is to redirect the prisoners' gaze inwards so that self-discipline produces a remodeled behavior. This mode of supervision finds echo in epistemic smothering 
wherein the subject modifies her knowledge (the case of Isma) or abstains from acquiring knowledge (the case of Shamsie). The airport episode has a traumatic effect on Isma who instinctively rejects a studio because it has a skylight: "with the memory of the Heathrow interrogation still jangling her nerves, she had been able to think only of surveillance satellites wheeling through the sky" (Shamsie, 2017a, p. 9). The opening episode shows a continuum of injustices, wherein Isma is wronged in her capacity as a knower, her free mobility, and her right for privacy.

\section{Ethical Confrontation With Injustice: The Case of Jihadists}

So far epistemic injustice, as a concept, provides us with philosophical tools to excavate prejudice-based practices as delineated in the narrative. The thorny question, however, is the ethical facet of this concept."In matters of epistemic injustice, the ethical is political" (Fricker, 2007, p. 8), thus Fricker concludes the introduction to her book. Among the several philosophical readings of Sophocles' tragedy, Simone de Beauvoir's juxtaposition of ethics and politics stands as a pertinent example. She describes Antigone as the epitome of "the intransigent moralist" who stands fast to eternal principles, while she refers to Creon as the prototype of "the political realist" who is obsessed by the state and the law. De Beauvoir focuses on the conflicting attitudes of the subjective moralist and the objective realist whose differences are irreconcilable. This raises the important question of whether ethics will never have a grip on politics and whether politics will keep impermeable to ethics (De Beauvoir, 2004, pp. 175-177). Shamsie's narrative also explores the conjunction between ethicizing politics and politicizing ethics. Her modern adaptation recuperates the central concern of the ancient play: the tense rapport between ethics and politics.

The case of Parvaiz offers a significant, albeit problematic, example. Aged nineteen, Parvaiz crosses a turbulent stage in his life. The memory of an absent dead father who fought in Afghanistan is romanticized by an ISIS recruiter. The young Parvaiz is easily manipulated and convinced to join ISIS and carry on his father's heroic deeds. Brain washed, the fragile Parvaiz readily believes in the Caliphate as

A place where migrants coming in to join are treated like kings, given more in benefits than the locals to acknowledge all they've given up to reach there. A place where skin colour doesn't matter. Where schools and hospitals are free, and rich and poor have the same facilities. Where men are men. Where no one has to enter haram gambling shops to earn a living, but can provide for his family with dignity. Where someone like you would find himself working in a state-of-the-art studio, living like a prince. Your own villa, your own car. Where you could speak openly about your father, with pride, not shame. (Shamsie, 2017a, p. 144)

A few months in Syria are enough to open Parvaiz's eyes to these lies. Witnessing horrible practices of killing and torture, he grows more convinced than ever that he has made a terrible mistake. Meanwhile, his citizenship is revoked and he is forbidden to go back home. Parvaiz presents a thorny epistemic case. The fact that he is unheard excludes him from any epistemic transaction and casts him as a subject without knowledge or someone whose knowledge cannot be taken into consideration.the narrative situation raises the following questions: has Parvaiz the right to generate social meaning? Can he convey knowledge to others by telling them? And can he make sense of his own political experience? (Fricker, 2017, p. 1). Answering these questions is at the heart of Fricker's ethics as related to epistemic practices. 
While I am aware that the situation I am speaking about is completely different from all the examples Fricker has given in her analysis, I maintain that the case of Parvaiz, the repentant jihadist, should be addressed within an epistemic frame of vision. Parvaiz, according to British law, is exiled without criminal trial and without the right to defense, presenting thus a clear case of both testimonial and hermeneutic injustice. To the question, how is it possible to issue such a law revoking citizenship for a dual national if he/she gets involved in terrorism? Shamsie answers: "it is possible, I would argue, because culturally there are too many people who think that if you aren't white and of Christian stock then you really aren't 'one of us'" (Shamsie, 2018a, para. 35). Revoking a dual national's citizenship is based on a racial prejudice and not on justice. It is in Isma's oxymoronic phrasing an "unjust law" (Shamsie, 2017, p. 196) and therefore it is a case of a distributive model of injustice, that is an unfair distribution of equal rights.

Taking this issue to classroom praxis raises a heated debate. In a country struck by terrorism like Tunisia, the discussion is not easy to handle. Students tend to amalgamate the specific case of Parvaiz with the different terrorist attacks against the country since 2011. The few students who think that Parvaiz has the right to go back to England receive angry responses. Shamsie is aware of such a response, as she declares: "I felt we are accused of sympathizing if we say that a young man who goes out there is anything but a monster" (Shamsie, 2017b, para. 3). So how can we speak about epistemic injustice in the case of Parvaiz without being accused of apologizing for terrorism? While there is no clear-cut answer to this question, the novel tries to provide a tentative response. A carefully nuanced delineation of radicalization and fundamentalism in the narrative is Shamsie's both aesthetic and strategic lines to subvert stereotypes. She creates a parallel between two opposite figures, namely the jihadist Adil Pasha and the home secretary Karamat Lone. While the former is a passionate fighter against oppression, the latter is an intractable politician, only concerned with the interests of the state. If Adil Pasha is a jihadist engaged in armed resistance to Western values, Karamat is called "a Lone Crusader taking on the backwardness of British Muslims" (Shamsie, 2017a, p. 35). The name given to Karamat is an ironic twist of the lone wolf terrorist, a lone-actor who kills for political reasons. Fusing and confusing the figures of the jihadist and the statesman is an invitation to look at the question of fundamentalism and radicalization from different perspectives.

Faced with this complicated topic, I provide my students with the following directives: the text confronts you with your ethical responsibility as a reader. It forces you to look at the topic and take position. To take position does not mean to have a moralistic judgment. Students are split between extreme refusal and cautious acceptance. The striking element, however, is the use of a violent semantic by the majority of students: "Exterminate all the brutes" (à la Conrad), "Jihadists must remain where they are", or "Ok, let them come back only to be executed in public." To the question, "do repentant terrorists have the right to explain their case?", the answer is almost unanimous: "No", "They stole their way to Syria in silence, let them keep silent to the end."

As a teacher of literature, I find my students' responses quite disturbing. For I believe that if literature teaches anything, it should teach empathy, which is a fundamental concern in ethics. "Empathy has played an important role in moral philosophy", argues Lawrence J. Hatab, "given that some thinkers (e.g., Hume, Schopenhauer, Rousseau) have maintained that sympathy or compassion is essential to ethics, as a kind of shared affect that is prior to rationality, principles, or rules" (Hatab, 2001, p. 359). The last part of the statement is 
extremely important, as well as relevant to Parvaiz's case, as it distinguishes empathy from social and juridical regulations. Fricker's (2007) analysis of the "virtuous hearer" (p. 80), which can be seamlessly projected onto a virtuous reader, stresses the empathetic engagement in a testimonial context. This explains her use of Harper Lee's novel, To Kill a Mocking Bird, being a narrative particularly attentive to empathy. Atticus' conception of empathy serves as a pivotal ethical concern in the narrative: "you never really understand a person until you consider things from his point of view... until you climb into his skin and walk around it" (Harper Lee,1960/1997, p. 33). This is Martha Nussbaum's (2002) central concern in her philosophical reflection on the global reader-citizen who should develop "the ability to think what it might be like to be in the shoes of a person different from oneself, to be an intelligent reader of that person's story, and to understand the emotions and desires that someone so placed might have" (p. 299). The novel raises such questions as: can we consider things from a terrorist's point of view? Can we climb into a jihadist's sister's skin and walk around it? Can we walk in the shoes of a fundamentalist? Philosophy comes at the rescue of literature here. To empathize does not mean to justify or apologize; it is "a vicarious sharing of an affect, which is most clearly shown when one is not directly undergoing the other's feelings and circumstances" (Hatab, 2001, p. 363). It is not uncritical, either, for our encounter with a character does not only imply identification, but also a process of interrogation and critique. And yet, "the first step of understanding the world from the point of view of the other is essential to any responsible act of judgment" (Nussbaum, 2002, p. 299).

\section{Conclusion}

An imbricated ethical and empathetic claim undergirds Shamsie's narrative. Both Fricker and Nussbaum show that a rewarding reading of literary fiction can be achieved by engaging in a philosophical ethical vision. This is what I have tried to do in this article by conjugating philosophy and literature. Taking cue from Shamsie's statement, "I hope anyone who reads my novel will see that you have to look at every individual case and decide how to respond" (Shamsie, 2018b), my attempt was primarily to confront a rather sensitive situation; not to dismiss it as a matter of course. The text urges the reader to apprehend a thorny situation and not to turn aside. Ostracizing entire communities and undermining their epistemic trustworthiness because of the War on Terror should be confronted as an ethical responsibility. Revoking a dual national citizen because of a terrorist act should also be scrutinized through epistemic lenses. Teaching Shamsie's narrative for two years now, I feel delighted with the fact that I have managed to win several reluctant students to the camp of an ethical and empathetic reading of the novel. Such a reading finds an impetus in Spivak's derivative position vis-à-vis the ethical and the epistemological: "Epistemological constructions belong to the domain of the law, which seeks to know the other, in his or her case, as completely as possible, in order to punish or to acquit rationally, reason being defined by the limits set by the law itself. The ethical interrupts this imperfectly, to listen to the other as if it were a self, neither to punish not to acquit" (Spivak, 2004, p. 83). Indeed, an ethical reading, in which one neither punishes nor acquits, is at the heart of an empathetic engagement with a literary text. Shamsie's narrative invites the reader to engage in an empathetic reading, wherein understanding someone's actions has nothing to do with approving them.

\section{References}


Ahmed, R. (2016, September 15). Typecast as a terrorist. The Guardian. Retrieved from https://www.theguardian.com/world/2016/sep/15/riz-ahmed-typecast-as-a-terrorist

Beauvoir de, S. (2004). Philosophical writings. Urbana: University of Illinois Press.

Bloom, H. (1994). The Western canon: The books and schools of the age. New York: Harcourt Brace \& Company.

Bloom, H. (2015, June 10). Preposterous 'isms' are destroying literature. The World Post. Retrieved from https://www.huffingtonpost.com/michael-skafidas/harold-bloompreposterous_b_7546334.html.

Chambers, C. (2018). Sound and fury: Kamila Shamsie's Home Fire. The Massachusetts Review, 59(2), 202-219. https://doi.org/10.1353/mar.2018.0029

Coady, D. 2017. Epistemic injustice as distributive injustice. In I. J. Kidd, J. Medina, \& G. Pohlhaus, Jr (Eds), The Routledge handbook of epistemic injustice (pp. 61-68). London: Routledge.

Dotson, K. (2011). Tracking epistemic violence, tracking practices of silencing. Hypatia, 26, 236-357. https://doi.org/10.1111/j.1527-2001.2011.01177.x

Eco, U. (1989). The open work. Trans. A. Cancogni. Cambridge: Harvard University Press.

Fortier, A. M. (2014). Migration studies. In P. Adey, D. Bissell, K. Hannam, P. Merriman, \& M. Sheller (Eds.), The Routledge handbook of mobilities (pp. 64-73). New York: Routledge.

Foucault, M. (1995). Discipline and punish: The birth of the prison (A. Sheridan, Trans). New York: Vintage Books.

Fricker, M. (2007). Epistemic injustice: Power and the ethics of knowing. Oxford: Oxford University Press.

Hatab, L. J. (2001). The ecstatic nature of empathy: A Heideggerian opening for ethics. Journal of Philosophical Research, XXVI, 359-380.

Heaney, S. (2005, November 2005). Search for the soul of Antigone. The Guardian. Retrieved from https://www.theguardian.com/stage/2005/nov/02/theatre.classics

Kirk, R. (1981). The moral imagination. Literature and Belief, 1, 37-49.

Koski, J. (2018, April 8). YOU reading group: Home Fire by Kamila Shamsie. Mail Online. Retrieved from https://www.dailymail.co.uk/home/you/article-5573077/YOUReading-Group-Home-Fire-Kamila-Shamsie.html.

Lauriola, R. (2014). 'Another' Antigone. The right to live and to die with dignity. Notes on Valeria Parrella's Antigone (2011). New Voices in Classical Reception, 1, 46-66.

Lee, H. (1997). To kill a mocking bird. London: Arrow Books.

Medina, J. (2017). Varieties of hermeneutic injustice. In I. J. Kidd, J. Medina, \& G. Pohlhaus, $\mathrm{Jr}$ (Eds), The Routledge handbook of epistemic injustice (pp. 41-52). London: Routledge.

Nicol, P. (2017, September 20). Author of the moment Kamila Shamsie on what it is to be muslim today. Evening Standard. Retrieved from https://www.standard.co.uk/lifestyle/esmagazine/author-of-the-moment-kamilashamsie-on-what-it-is-to-be-a-muslim-today-a3639416.html.

Nussbaum, M. ( 2002). Education for citizenship. Studies in Philosophy and Education, 21, 289-303. https://doi.org/10.1023/A:1019837105053

Pohlhaus, G. (2017). Varieties of epistemic injustice. In I. J. Kidd, J. Medina, \& G. Pohlhaus, $\mathrm{Jr}$ (Eds), The Routledge handbook of epistemic injustice (pp. 13-26). London: Routledge.

Salter, M. B. (2008). (Ed). Politics at the airport. Minneapolis: University of Minnesota Press.

Shamsie, K. (2017a). Home fire. London: Bloomsbury Publishing.

Journal of Contemporary Issues in Education, 2020, 15(2), pp. 23-35.

(c) Author(s), Creative Commons Attribution 4.0 (CC BY 4.0) licence.

http://ejournals.library.ualberta.ca/index.php/JCIE

doi 10.20355/jcie29404 
Shamsie, K. (2017b, August 27). Interview by Vanessa Thorpe. The Guardian. Retrieved from https:/www.theguardian.com/books/2017/aug/27/kamila-shamsie-home-fireman-booker-longlisted-author-interview.

Shamsie, K. (2018a, November 17). Exiled: The disturbing story of a citizen made UnBritish. The Guardian. Retrieved from https://www.theguardian.com/books/2018/nov/17/unbecoming-british-kamilashamsie-citizens-exile

Shamsie, K. (2018b, April 4). Interview by Devina Heriyanto. The Jakarta Post. https://www.thejakartapost.com/life/2018/04/04/interview-kamila-shamsie-talksabout-home-fire-minorities-and-terrorism.html. Accessed 7 September 2019

Sheller, M. (2018). Theorizing mobility justice. Tempo Social, 30(2), 17-34.

Spivak, G. C. (1988). Can the subaltern speak? In C. Nelson \& L. Grossberg (Eds.), Marxism and the interpretation of culture. London: Macmillan.

Spivak, G. C. (2004). Terror: A speech after 9/11. Boundary, 2(31), 81-111.

Spivak, G. C. (2017, March 2). Destinerrance. [Paper presentation]. International Book Fair of Tunis, Tunisia.

Spivak, G. C., \& Harasym, S. (1990). The post-colonial critic: Interviews, strategies, dialogues. New York: Routledge.

WaThiong'o, N. (2000). Borders and bridges: Seeking connections between things. In A. K. Fawzia \& K. Seshadri-Crooks (Eds.), The pre-occupation of postcolonial studies (pp. 119-125). Durham: Duke University Press. 